\title{
University/School Library Collaborations to Integrate Information Technology into Resource-Based Learning Activities
}

\author{
Ray Doiron, Ph. D. \\ <raydoiron@upei.ca> \\ Associate Professor \\ Faculty of Education, University of Prince Edward Island \\ Canada
}

\begin{abstract}
If the goal of teacher-librarians is to work with teachers to develop information literacy, then how do we model this collaboration for pre-service teachers during their teacher education program? This question was explored in a research study involving university researchers, teachers, and teacher-librarians in six elementary schools in Canada. Learning projects arose from collaborations among the pre-service teachers, classroom teachers, and teacherlibrarian as they developed IT projects that were integrated into the pre-service practicum. Data were collected on the learning strategies children used and on the collaborative relationship established between the pre-service teachers and the teacher-librarian. This study tracked how pre-service teachers reacted to working with teacher-librarians. Results indicated these projects created authentic environments where pre-service teachers learned the role of the teacher-librarian and how the curriculum development process associated with resource-based learning develops through school library programs.
\end{abstract}

\section{Introduction}

Throughout North America, pre-service teacher education programs are struggling to adapt to a rapidly changing educational context (Driskell \& Cobbin, 1997; Shapson, 1998) particularly in the area of integrating information technologies into their education courses and practicum experiences. At the Faculty of Education at the University of Prince Edward Island, we recently replaced our four-year undergraduate and one-year, post-degree programs with a new two-year, post-degree program with an enhanced and extended practicum and many newly with professional development who designed courses. In some of the traditional approaches to preparing new teachers, students would study various methods, practice them amongst themselves and then go into the school system to "practice" their skills in a teaching practicum. Starting in 1997, we were looking for ways to integrate into our program more authentic situations in which pre-service teachers could experience how curriculum emerged in classrooms and how teachers were provided en new curriculum was implemented. Like other programs, we were faced with pre-service teachers with high expectations that technology would play a large role in their development as new teachers (Duffield, 1997). In addition, we were faced with many pressures to increase the role of technology in both the 
way courses are taught and in the way pre-service teachers are expected to use information technologies in the planning, preparing and presenting of their lessons.

Both of these thrusts connected very well with the need to prepare new teachers to work with teacher-librarians and to have them graduate with an understanding of how resource-based learning develops through an integrated school library program. Since teacher-librarians play such a leadership role in the use of information technologies, it seemed a natural connection to have pre-service teachers work with teacher-librarians in the development of information technology projects that would model how information technology becomes integrated into learning outcomes associated with information literacy. It also created an ideal research environment to examine what pre-service teachers learned about the role of teacher-librarians and school libraries.

\section{Background to the Study}

This study was part of a major two-year project that examined effective ways to integrate information technologies into the elementary school curriculum. Throughout the study, Teaching and Learning with Information Technologies (TLT), experienced classroom teachers, teacher-librarians, and pre-service teachers developed curriculum projects that involved children in the use of Internet, CD-ROM packages, email and web-based learning environments. All projects were integrated into existing language arts, social studies and mathematics programs or involved information literacy skills/strategies in grades $2,3,4$, and 5. All of the projects were designed to achieve learning outcomes from the Atlantic Provinces Education Foundation (APEF) Curriculum. The researchers and pre-service teachers from the University of Prince Edward Island collaborated with educators in several schools across Prince Edward Island and with curriculum consultants from the Department of Education. The projects were a response to the increasing pressure for classroom teachers and teacherlibrarians to use more technology in their teaching, as well as the expectation that pre-service educators ensure that new teachers entering the school system are well-prepared to use information technology in a variety of ways.

We created project-based, collaborative learning situations (Driskell \& Cobbin, 1997) in which new teachers and experienced teacher-librarians could work together to integrate various information technologies into authentic resource-based learning activities across the curriculum. Several examples of the projects include: 1) grade two students used C-D-ROM software to develop their patterning skills; 2) grade four students visited eight Internet sites and evaluated the benefits of each site; 3 ) grade five students used an electronic environment to collect and deposit information on their local community and communicated with other students in Iceland and Newfoundland; 4) grade three students used a CD-ROM package to collect information on animals; 5) grade five students used Internet sites to collect weather data for their local community; and 6) grade five students used word processing in the editing and revising of their poetry writing. The cycle of planning and preparing the projects, as well as the implementation and evaluation of the projects involved all partners and required a great deal of discussion and problem-solving along the way.

There were four faculty researchers involved in the TLIT project and each researcher focussed on one curriculum area: language arts, mathematics, social studies, and information literacy. 
Although pre-service teachers and teacher-librarians were involved with projects in all areas, this article shares the results from the work done in the information literacy area and involves results from only two of the six schools that took part in the whole project.

\section{Goals of the Study}

Within the larger research project, there were many goals related to information technology. In the context of pre-service teachers working with teacher-librarians, these were the primary goals:

- to create authentic learning situations where pre-service teachers could work along side inservice teachers to develop applications of information technology in existing curriculum,

- to create a collaborative environment for exploring the issues around integrating information technology across the curriculum,

- to develop effective teaching strategies for using information technology across the curriculum,

\section{Research Methods}

As part of the whole Teaching and Learning with Information Technology project (TLIT), preservice teachers met with teachers and teacher-librarians to design integrated activities that used information technologies. For this study, I was responsible for five pre-service teachers and together we worked with two teacher-librarians in two small elementary schools in Prince Edward Island. These schools had well-established school library programs and a full-time teacherlibrarian. Teachers and the teacher-librarian met regularly to discuss curriculum and to establish resource-based learning activities that were part of the existing school curriculum and that involved children in projects in the school library. The university students were aligned with the teacher-librarians as part of the collaborative planning and teaching team and as someone who would take a leadership role in using information technology.

As the university researcher, I became part of the team to observe how the various educators were dealing with the pressure to use more IT in their programs, how they were making connections to their curriculum and how the pre-service teachers would work when in a collaborative working environment. I made notes during the planning of the projects, as well as keeping a reflective journal between meetings. I met with the teacher-librarians privately to monitor how the preservice students were doing and generally fulfilled my role as faculty supervisor for students who were on a field practicum. I met with the pre-service teachers privately to help them with any questions or concerns they had and to give them information on how the collaborative planning process usually works. I generally modelled for them how teacher-librarians work with teachers to involve them in collaborative curriculum work.

In addition to the data-collection they were expected to do during the actual implementation of the IT projects with children, the pre-service teachers also keep research journals in which they 
were expected to keep notes during their planning sessions and to reflect on the collaborative process at times of their own choosing. These journals and my own journal were examined for common themes and issues and a set of interview questions was developed. Each pre-service teacher was interviewed at the end of the TLIT Project and the results of those interviews form the basis of the present analysis. The five pre-service teachers who were interviewed responded to several questions on their work on the TLIT Project and these three questions related directly to their work with the teacher-librarian: 1) what they learned about the curriculum planning process; 2) how they would use information technology in their own teaching; and 3) what they learned about the role of the teacher-librarian and school library programs.

\section{Results of the Interviews}

The interview data was reviewed for details on the three topics for discussion: the curriculum process, instructional uses of IT and working with the teacher-librarian. The questions generated a positive discussion among all of the pre-service teachers and several recurring themes became evident.

\section{The Curriculum Process.}

All five pre-service teachers felt that their work on the TLIT project was invaluable in their understanding of the curriculum process. They listed several important areas to be considered in curriculum implementation such as clear objectives, pre-planning and being well-prepared in advance. They had to be sure the technology was working, that the approach they wanted to take was well thought out and that they had considered all potential pitfalls before they proceeded. They felt the activities that they were involved with helped them learn what the prior knowledge the children have of using IT and that these children see using computers as an attractive and enjoyable activity. They also noted how the children need to be taught some basic navigational skills and to move beyond the "game" or "fun" attitude and really be given meaningful learning experiences. They had to explore alternative ways of making the technology available since there was a great deal of variance in the what IT was available and where they could access it. They also note dhow teachers and teacher-librarians are aiming to integrate the technology and not just have it as an add-on to their programs. They noticed how knowledgeable the teacher-librarians were about the information technologies and how they fit in to the overall curriculum.

\section{Using IT in their Teaching.}

This question of how the pre-service teachers felt they would use IT in their teaching careers generated a great deal of discussion. Most felt it was "a fact and reality of our future teaching" and that it would be used "in everything I do!" They recognize it as an essential part of how they will teach and how their students will learn. They suggested computers can "accommodate many learning skills and styles" and can make it easier for "dealing with multiple intelligences." They made several references to "using communication technologies to connect students and have them 
collaborate with peers." They predominately cited the technology as an "information resource" that is particularly important in "library research projects" and "as a learning tool to promote critical thinking" and "to teach students to be effective information managers." They were particularly impressed with how the teacher-librarians knew the technology so well and could use it effectively.

\section{Working with the Teacher-Librarian.}

All of the pre-service teachers were greatly impressed with the way teacher-librarians ran their school library programs. They were "amazed at how they keep all of the various aspects of their jobs going at once," and "how they want to work so closely with teachers." They expressed great interest in how "all children are welcome in the school library" and how "they can work at their own level in here." In one school, the teacher-librarian had just moved to that school and she was trying to build new relationships with a whole new staff and the pre-service teachers at her school expressed how impressed they were "with the professional way she approached teachers to get them involved in the library." From both schools they recognized how important the principal is and how "he comes into the library often to see what is going on."

The pre-service teachers stated how they "never knew how much teaching goes on in here" and how "the teacher-librarian really knows about technology." It impressed them that teacherlibrarians "make such detailed plans and keep track of everything," and they were impressed with how they work with teachers to evaluate the students' work. They enjoyed the "the learning stations set-up" and how the projects "were more than just fill in the blanks or answering questions." They liked "all the different materials available for teaching," and they "liked working with children from different grades." They repeatedly expressed their great respect for what the teacher-librarians were trying to do.

\section{Issues Facing New Teachers.}

The number one issue these pre-service teachers cited was "the lack of information technology resources available to the average teacher." Resources, money and the "limitations of funds in the schools" were recurring themes. They saw inequity of access to current technologies as a major issue and wondered how the system will "remain current with changes in usable technologies?" One pre-service teacher wondered if the school administrators and fellow teachers on staff will "support my efforts in using available technologies in meeting curriculum goals" and if they will be allowed "to work information technologies into curriculum where it has never been used before." Will they be able "to make it a daily tool?" Three mentioned how they felt other preservice teachers don't know how a school library should work and they are missing what they had during their work with the TLIT Project. They also wondered if they went to other schools would they see teacher-librarians working in the same way as they experienced in these schools.

Two of the participants mentioned issues around security and censorship with questions about "what should be accessible on the Internet." Two were also worried if they will be able to stay current themselves and "keep up to date with software and skills." 


\section{Discussion}

As a research team. we were cognizant of the limitations of an "intuitive analyses of what works" that Windschitl (1998) claims can limit research results, but we also worked closely as a collaborative team as suggested by John-Steiner, et al. (1999) to ensure "that shared views, construction of new knowledge, and joint work" were significant aspects of our collaboration. The discussion with pre-service teachers before, during and after the projects helped in this process and have provided us with several new understandings that will inform our future work in this area.

In a very real way, we were modelling the teacher-as-researcher process for our pre-service teachers. They reacted positively to working in a research environment where they established areas to examine, set up procedures for pursuing their questions, working with the children to complete the projects and then writing about what they observed. They felt they were "able to see the stages of the entire research process" and to see "how educational change can happen." This experience will stay with these pre-service teachers well into their careers and it helped them develop their reflective practice skills that are essential to sustain a life-long teaching career.

Just as importantly, the TLIT project was an authentic learning environment for all who were involved with it. It created an environment where we could see what the real problems were facing teachers and teacher-librarians as they attempt to integrate information technologies. In the words of one pre-service teacher, the advantage in working in this environment was "the opportunity to think about and see the potential for using information technologies in what I do and in what I teach." They could also see the many issues facing teacher-librarians who are trying to involve all teachers and their students in information literacy activities.

By mounting IT projects, the pre-service teachers came face-to-face with the types of technology available, with the curriculum into which they must try to integrate IT and with the variety of experiences students and teachers have had with IT. The pre-service teachers identified the availability of computer hardware and other technological resources as the main problem facing them as they take up new teaching positions. There appears to them to be inequity in the quantity and quantity of computer resources, where "some schools have many computers, while others are limited in what is available." They wonder "will there be resources available to me and my students?" or will the system help them in "keeping up to date with software and skills?"

These are the same issues all educators face and the pre-service teachers had many opportunities to explore innovative ways of using IT so that all students had access and opportunities to use it. Teaching and learning activities, such as learning stations in the school library and small group activities for using one computer in the classroom were all modelled for them. The TLIT project placed them in problem-solving situations where they had to find ways to hold to their principles for integrating IT, while trying to deal with the impediments to them such as technical failures, inequitable access and old equipment. In addition to issues around availability of technology, these pre-service teachers worked with two strong models of integrated school library programs and thus have a much better sense of what to expect when they are working in another school 
situation. Future projects will build on this authenticity and should be encouraged to spread across the pre-service program into other areas of curriculum implementation and pre-service development.

Related to the authentic nature of this project is how curriculum development is often something that pre-service students can learn about in lectures, but never really practice until they get into the school for a practicum or in their first job. In the TLIT project, they practiced many of the components of the curriculum development process and the ways teachers and teacher-librarians work with educational innovations to incorporate them into their repertoire as teachers. The preservice teachers had to examine the existing curriculum and the new programs that have been implemented recently, as well as learning how information technology is integrated into learning outcomes. They had to learn about information literacy and how a school library program becomes integrated across the curriculum. They had to establish grouping arrangements, meaningful learning activities, as well as design lessons using IT. They worked with the curriculum process in dynamic and authentic situations with the support of the school-based teacher-librarians and the university researchers. They learned "it is important to have clear objectives," that "it takes a lot of planning" and that they "must maintain good communication." They learned "how to work information technologies into the curriculum", "how students use information and perform research", and "how to use learning stations and information resources." These are all important aspects of curriculum development and these pre-service teachers had a chance to see their plans come to fruition and to analyse their success. These are important skills even if they never become teacher-librarians; they will know how a school library program can help them as classroom teachers and how a teacher-librarian can support them and collaborate with them to make for more effective teaching and learning.

One of the real advantages of this type of project is how pre-service teachers are empowered as teachers. They are not simply learning about teaching; they are actively involved in the process of creating learning environments and in this case bringing about innovation. They were able to work along side the in-service educators and make real contributions to the educational programs in these schools. Throughout the TLIT project, we were inching towards a collaboration where the pre-service teacher could show leadership, energy and commitment to something new, while the sponsoring teachers and teacher-librarians were acting in their traditional mentoring roles by accepting the pre-service teachers into their classrooms and school libraries. Not all situations were equally successful, but we were successful in creating many of the conditions essential to the collaborative planning and teaching process. The pre-service teachers responded positively to being part of a team where they had input and a meaningful role to play in the development and implementation of the IT projects. They felt "able to mentor and collaborate with other teachers and administrators" and that they "had first-hand experience in a collaborative educational project." 


\section{Implications and Applications}

Although the sample of pre-service teachers used in this study was small, there are at least early indications that setting up collaborative teams that include in-service teachers and teacher/librarians, pre-service teachers, university researchers and education consultants have great potential for affecting change in the way we introduce innovation to the system and how we prepare new teachers. The fact that these four educators came together to explore innovative uses for information technology was feat enough, while the results suggest we have harnessed our separate energies and focussed them on creating real change. This "change as collaborative inquiry approach" (Wagner, 1998) leads to several suggestions for future applications of this emerging model.

First of all, curriculum developers need to recognize pre-service teachers as an untapped resource for introducing educational innovation. They need to be involved as active participants in the change process associated with curriculum innovation and not limited to being perceived as one more target group consultants need to get to early and get them aboard. These pre-service teachers have demonstrated that they can take part as full partners in research projects, curriculum change initiatives and as part of collaborative planning and teaching projects. More importantly, it appears that what they learned from these projects has become part of the way they see themselves as educators. This could be the teaching experience that really creates beginning teachers with a better understanding of the role of teacher-librarians and school libraries. In the future, consultants could involve pre-service teachers in pilot projects, curriculum planning sessions and as workshop presenters and participants.

In a similar vein, curriculum consultants need to recognize the role action research plays in curriculum innovation and so try to have field-based research be part of any new initiatives they want to implement. This will provide them with authentic information on the impact their new program or curriculum change will have on teaching and learning. There are effective models available for implementing field-based research (Hemmeter et al., 1996) and when they are applied within the collaborative approach used in this study, there is a great potential for meaningful change. University educators also should see that placing pre-service teachers with teacher-librarians provides them with authentic learning experiences and teaches them a great deal about effective teaching strategies.

A second implication centres on the relationship between the pre-service teachers and the inservice teachers and teacher-librarians who offer to act as their sponsoring teachers during their school-based practicum. Pre-service teachers in this project acted as mentors to in-service teachers as they led the way with the use of information technology. They were very comfortable with using these technologies and they saw them as natural tools to use in their teaching. This meant the in-service teachers were being supported in their acceptance and application of IT, while the pre-service teachers were supported in their development of management and instructional skills. In the future, other projects could be set up around IT and also other areas of the curriculum, so that the natural curiosity and energy of new teachers can be harnessed and used to help motivate in-service teachers work with new innovations. For example, many of the 
constructivist approaches applied in pre-service programs require a great deal of collaborative learning. Pre-service teachers may want to use more cooperative learning in their teaching, but a classroom teacher may not feel like trying it. Together they could both learn by using a similar team approach, where the pre-service teacher could develop activities for using cooperative learning and the in-service teacher could support and facilitate their work with their children. Attaching the pre-service teacher to the teacher-librarian team could also help model for classroom teachers how the collaborative teaching approach found in school library programs really works. The pre-service teachers in this project thrived on this partnership and found the teacher-librarian really acted as a mentor for them.

\section{Conclusion}

Authentic learning environments are easy to identify, but harder to create. Means and Olson (1994) suggest that challenging tasks are the starting point for activities that are seen as worthwhile and meaningful and that heterogeneous and collaborative groups are at the heart of successful learning. From our work on the TLIT project, it is clear that these same principles hold when they are applied to an adult learning situation where educators are exploring the uses of IT for teaching and learning and particularly when working in the collaborative planning and teaching process. If we believe in authentic learning, collaboration and constructivist principles and, if we want to implement collaborative planning and teaching, then this project demonstrates that all educators must be involved in the process and that the change that the role of the teacherlibrarian brings to how we teach and how children learn will not be effective if we do not use approaches like this,

If having a strong commitment to using information technologies (Hope, 1997) and to the role of the teacher-librarian in developing information literacy is essential to the success of students' use of technologies, then these pre-service teachers demonstrated they believe strongly in the use of information technology and that the experience they had with this TLIT project has given them the chance to develop some of the reflective teaching skills necessary to maintain their commitment and to realize their vision for using information technology. In addition, they have not only seen a teacher-librarian working in the collaborative planning and teaching process, they have been part of that process and have developed a deep understanding of how the school library program is essential to the integrated use of information technology and students' information literacy. 


\section{References}

Driskell, T. and Cobbin, J. (1997). A key to technology integration into the classroom: The campus facilitator. SITE Annual '97, Technology and Teacher Education, CD-ROM version. Charlottesville, VA: Association for the Advancement of Computing in Education.

Duffield, J.A. (1997). Trials, tribulations and minor successes: Integrating technology into preservice teacher preparation programs. TechTrends, 42 (4), p. 22-26.

Hemmeter, M.L., Doyle, P.M., Collins, B.C and Ault, M.J. (1996). Checklist for successful implementation of field-based research. Teacher Education and Special Education, 19 (4), p. 342-354.

Hope, W.C. (1997). Teachers, computer technology and the change process. The Clearing House, 70 (4). 191-193.

John-Steiner, V., Weber, R.J., \& Minnis, M. (1998). The challenge of studying collaboration. American Educational Research Journal, 35 (4), p. 773-783.

Means, B., \& Olson, K. (1994). The link between technology and authentic learning. Educational Leadership, 51 (7), p. 15-18.

Shapson, S.M. (1998). Teacher education at a turning point. Orbit, 29 (2), p. 10-14.

Wagner, T. (1998). Change as collaborative inquiry: A "constructivist" methodology for reinventing schools. Phi Delta Kappan, 79 (7), p. 512-517.

Windschitl, M. (1998). The WWW and classroom research: What path should we take? Educational Researcher, 27 (1), p. 28-33.

$$
\text { Www. upeica/ fac-ed/teit/one.htm }
$$

